\title{
OPTIMALISASI PENCAHAYAAN GEDUNG BERPEDOMAN PADA STANDAR NASIONAL DAN GREEN BUILDING COUNCIL INDONESIA
}

\author{
Taufik Hamzah ${ }^{1}$ \\ ${ }^{1}$ Jurusan Teknik Sipil Politeknik Negeri Bandung, 40012 \\ E-mail : taufik.hamzah@polban.ac.id
}

\begin{abstract}
ABSTRAK
Desain gedung dengan pencahayaan dan penghawaan alami yang baik sudah menjadi suatu keharusan saat ini dan dimasa mendatang. Hal ini bermanfaat bagi penghematan konsumsi energi dan terciptanya bangunan yang sehat serta ramah lingkungan. Oleh sebab itu terapan konsep green building secara tepat terutama didaerah tropis seperti Indonesia sangat diperlukan. Tiga aspek penting mengapa perlunya penerapan konsep green building, yaitu pemanasan global (global warming), perubahan iklim (climate change) dan terjadinya penurunan kualitas lingkungan (environmental deteriorations). Penelitian ini merupakan penelitian dasar yang menyangkut bidang ilmu rekayasa dengan tema teknologi konservasi energi pada desain gedung. Jenis penelitian adalah descriptive-method dengan metode pendekatan mixed method, teknik pengumpulan data menggunakan triangulasi yaitu survei, observasi visual dan pengukuran. Sebagai objek kasus penelitian adalah Gedung Call Center Telkomsel (CCT) Bandung, di mana hampir keseluruhan desain arsitektur eksterior (building envelope) menggunakan material kaca. Dugaan secara visual bahwa desain gedung seperti ini akan memberikan pengaruh terhadap kenyamanan termal di dalam sebuah ruangan yang disebabkan oleh radiasi matahari. Penelitian ini bertujuan mengoptimalkan pencahayaan dalam gedung sesuai dengan standar dan konsep green building. Luaran penelitian dan luaran tambahan adalah Laporan akhir, publikasi pada jurnal terakreditasi dan desain ulang fasad Gedung CCT sesuai standar pencahayaan dan konsep bangunan hijau (green building) yang ramah lingkungan serta hemat energi.
\end{abstract}

Kata Kunci: Green Building, Konsumsi Energi, Sun Shading

\begin{abstract}
Building design with good natural lighting and ventilation has become a necessity today and in the future. This is beneficial for saving energy consumption and creating healthy and environmentally friendly buildings. Therefore, it is necessary to apply the concept of green building appropriately, especially in tropical areas like Indonesia. Three important aspects are why it is necessary to apply the green building concept, namely global warming, climate change, and environmental deterioration. This research is basic research concerning the field of engineering science with the theme of energy conservation technology in building design. This type of research is a descriptive method with a mixed-method approach, the data collection technique uses triangulation, namely surveys, visual observation, and measurement. As the object of the research case is the Bandung Call Center Telkomsel (CCT) building, where almost the entire exterior architectural design (building envelope) uses glass material. Visual assumptions that the building design like this will have an influence on the thermal comfort in a room caused by solar radiation. This study aims to optimize the lighting in the building according to the green building concept and standards. The research outputs and additional outputs are the final reports, publication in accredited journals, and the redesign of the CCT building façade according to lighting standards and green building concepts that are environmentally friendly and energy efficient.
\end{abstract}

Keywords: Green Building, Energy Consumption, Sun Shading

\section{PENDAHULUAN}

Bangunan merupakan suatu benda yang memberikan kontribusi terbesar bagi peningkatan pemanasan global. Berdasarkan hasil penelitian yang dilakukan bahwa desain selimut bangunan dengan material kaca, dapat berkontribusi besar terhadap efek panas rumah kaca. Di samping berkontribusi juga terhadap emisi CO2 sekitar 700 billions metric ton pada tahun 2000 [1]. Oleh karena itu pembangunan dengan konsep bangunan hijau (green building) dengan konsep ramah lingkungan, sehat dan efisiensi penggunaan panas matahari sudah harus diaplikasikan pada desain bangunan gedung. Hal ini dilakukan untuk mengurangi efek pemanasan global (global warming). Efek yang ditimbulkan akibat pemanasan global ini dari tahun ke tahun semakin besar. Efek ini dapat dikurangi dengan sebanyak-banyaknya menggunakan sumber daya alam yang efisien sehingga terwujudnya bangunan yang sehat, hemat energi dan ramah lingkungan. Dalam pengaplikasiannya, desain konsep bangunan hijau (green 
building) berfokus dalam hal ekonomi, utilitas, durabilitas, dan kenyamanan penghuni. Untuk menghindari atau mengurangi pemanasan global akibat kontribusi yang besar dari pemakaian alat pengkondisian udara (Air Conditioner--AC) dan penerangan pada bangunan, maka konsep bangunan hijau (green building) ini sudah harus diterapkan pada perancangan bangunan. Lebih jauh dan sempurnanya konsep ini maka dapat dipadukan dengan bangunan pintar (smart building).

Gedung yang diambil sebagai obyek penelitian adalah Gedung Call Center Telkomsel (CCT) yang merupakan gedung swasta empat (4) lantai yang berfungsi sebagai tempat pelayanan konsumen mengenai fasilitas yang disediakan dari pihak Telkomsel. Dinding eksterior (building envelope) gedung CCT dirancang menggunakan kaca jenis stopsol supersilver glass dengan varian warna clear dan green (Gambar 1). Orientasi bangunan menghadap Timur-Barat, sehingga cahaya matahari langsung yang masuk ke dalam gedung cukup besar sehingga suhu dalam ruangan meningkat akibat radiasi matahari. Sebaliknya pencahayaan siang hari (pencahayaan alami) di dalam gedung secara visual masih kurang (Gambar 2). Ini dikarenakan pemakaian daya, jumlah dan armatur lampu tidak maksimal, sehingga mengakibatkan pencahayaan ruangan kerja tidak memenuhi persyaratan minimum yang disyaratkan SNI 03-6575-2001 tentang Tata Cara Perancangan Sistem Pencahayaan. Tidak optimalnya pencahayaan berpengaruh juga terhadap produktivitas.

Di samping itu, jumlah daya yang dihasilkan besar dikarenakan gedung ini menggunakan jenis lampu konvensional. Sehingga energi panas yang ditransmisikan ke komponen Arsitektur gedung dapat menimbulkan efek panas yang berlebihan. Oleh karenanya konsumsi energi untuk penggunaan alat pendingin udara (AC) menjadi besar.

Oleh sebab itu dibutuhkan desain bangunan gedung yang dapat mengoptimalkan pencahayaan dan mengurangi penggunaan yang berlebihan. Penelitian terkait dengan optimalisasi pencahayaan terhadap Gedung CCT meliputi beberapa ruangan pada lantai 1, 2, 3 dan lantai 4. Sampel ruangan diambil dari hasil survei awal terhadap ruangan-ruangan dengan tingkat pencahayaan kurang.

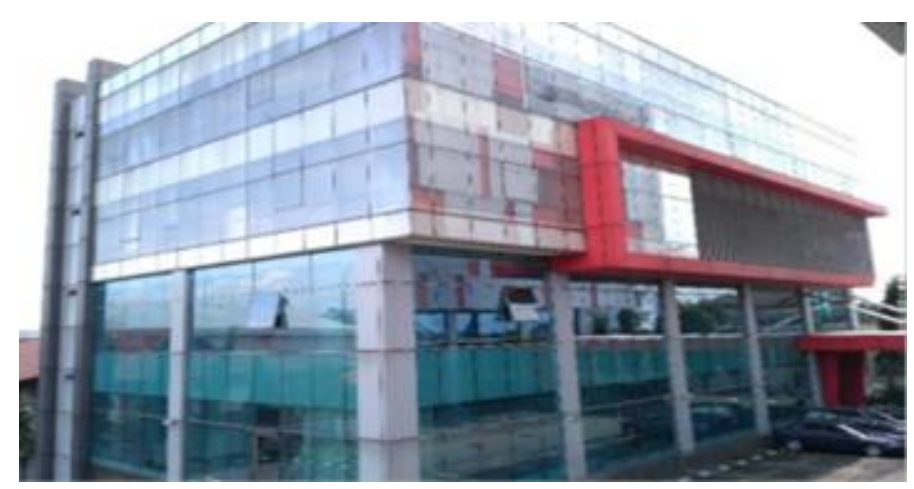

Gambar 1. Eksterior Gedung CCT

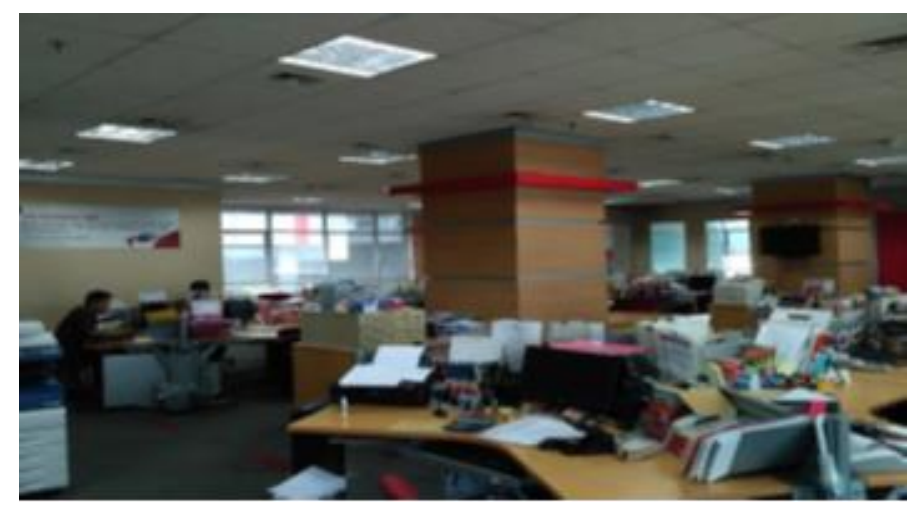

Gambar 2. Interior (Zona Kantor) Gedung CCT

\subsection{Perumusan Masalah}

Berdasarkan hasil survei awal terhadap gedung CCT, peneliti dapat merumuskan permasalahan yang ada pada gedung tersebut bahwa akibat desain selimut gedung (building envelope) dengan material kaca memberikan transmisi panas yang berlebihan ke dalam bangunan. Di samping desain fasad gedung CCT yang kurang memenuhi persyaratan sehingga sangat mempengaruhi kenyamanan dan kesehatan penghuni dalam gedung. Permasalahan lain yang dapat dirumuskan adalah konsumsi energi listrik yang besar untuk sistem penghawaan ruangan dengan alat pengkondisian ruang (AC) serta konsumsi daya lampu yang 
berlebihan sehingga tidak hanya memberikan efek panas yang tidak nyaman bagi penghuni tetapi juga tidak efisien terhadap pemakaian energi.

\subsection{Ruang Lingkup Penelitian}

Ruang lingkup penelitian mencakup rancangan pencahayaan alami mempengaruhi ruangan-ruangan yang di tinjau pada Gedung CCT jalan Soekarno-Hatta Bandung, yaitu:

1. Merancang ulang (Redesign) fasad Gedung CCT yang sesuai standar untuk mengoptimalkan pencahayaan serta penghematan konsumsi energi pada operasional Gedung CCT. Serta melakukan perhitungan\ pengaruh sun shading terhadap pencahayaan alami serta beban alat pengkondisian udara (Air Conditioner--AC) di ruangan-ruangan yang ditinjau.

2. Mengoptimalkan penggunaan energi pada pemakaian lampu di Gedung CCT dan mengacu pada standar green buidling serta dilakukan perhitungan efisiensi total biaya hasil dari perancangan terhadap biaya operasional yang ada (existing operational costs).

\subsection{Ruang Lingkup Penelitian}

Koreksi terhadap full glass building envelope design dengan Tingkat Ketersiapan Teknologi (TKT) 3.

\section{TINJAUAN PUSTAKA}

Kategori inovasi pada desain bangunan gedung dilakukan berdasarkan tipe, sistem, arsitektur dan modular. Berdasarkan dari beberapa penelitian sebelumnya dapat disimpulkan bahwa inovasi desain gedung hemat energi dapat disesuaikan dengan iklim setempat. Sebagai Negara tropis di mana sinar matahari berlimpah, sudah barang tentu inovasi desain gedung terhadap pencahayaan alami dapat dengan mudah dilakukan. Dengan demikian desain gedung hemat energi (dalam konteks pencahayaan dan penghawaan) dapat dicapai [2].

Efek negatif yang timbul pada desain selimut bangunan dengan material kaca adalah konsumsi energi yang berlebihan. Kondisi seperti ini dapat meningkatkan koefisien pertambahan panas matahari (solar heat gain coeficient), serta koefisien transmisi cahaya (ultraviolet transmittance) pada gedung [3].

Desain yang dapat dipakai untuk menghindari efek negatif akibat transmisi panas yang berlebihan adalah komponen pelindung matahari (sun shading component). Desain ini adalah salah satu cara dan langkah awal agar tercapainya kenyamanan termal gedung dengan penempatan yang tepat. Tiga model desain sun shading yang dapat dipakai adalah interior shading device, midpane shading device, dan exterior shading device. Interior shading device ini dipasang pada bagian dalam bangunan. Sedangkan mid-pane shading device, dan exterior shading device dipasang di antara panel atau kaca jendela. serta di bagian luar bangunan, vertikal dan horizontal [4,5] (Gambar 3).
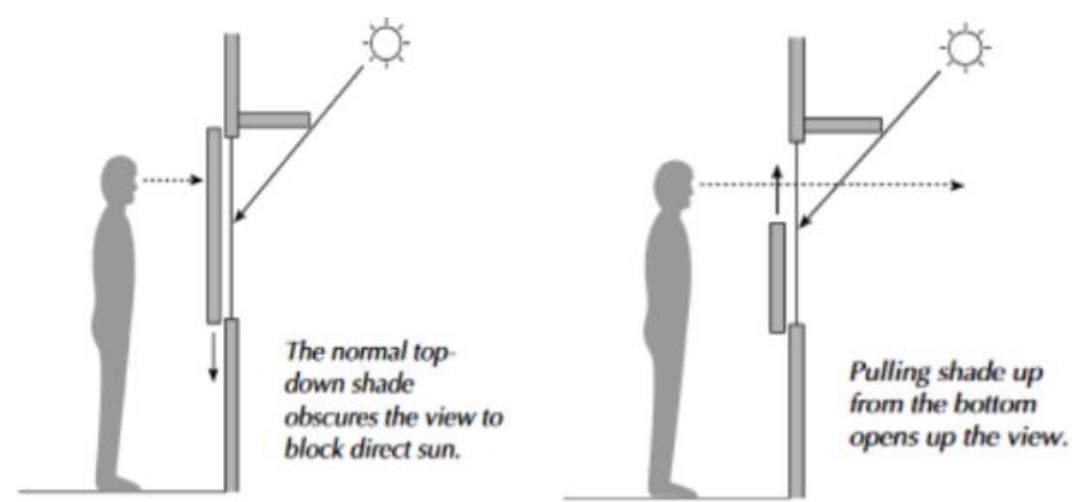

Gambar 3. Interior shading device

Pencahayaan alami adalah sumber pencahayaan tidak langsung yang berasal dari sinar matahari karena pencahayaan langsung dari matahari akan menghasilkan silau dan panas yang dapat mengganggu kenyamanan aktivitas di dalam ruangan. Pencahayaan alami ini biasa dimanfaatkan untuk menerangi dalam bangunan melalui bukaan-bukaan yang terpasang pada bangunan. Salah satu keuntungan pencahayaan alami yaitu dapat membunuh bakteri yang ada dalam bangunan [6].

Keuntungan dari memaksimalkan pencahayaan alami yaitu dapat meminimalisir penggunaan energi listrik terutama penggunaan lampu yang bisa mencapai $25 \%$ dari pemakaian energi keseluruhan. Pemakaian energi pada penggunaan lampu menurut riset bisa sampai 25\% dari total penggunaan energi keseluruhan). Hal ini menjadi penting untuk dipertimbangkan dalam pengelolaan biaya operasional bangunan dengan memaksimalkan pencahayaan alami. Pencahayaan alami dapat dioptimalkan dengan 
mendesain bangunan dengan benar karena ketersediaan cahaya alami pada suatu bangunan tergantung pada planform, orientasi bangunan, lokasi bangunan, ukuran bukaan, karakteristik kaca, dan refleksi internal maupun eksternal bangunan [7].

\section{METODOLOGI PENELITIAN}

\subsection{Metode Penelitian}

Referensi [8,9] menunjukkan bahwa penelitian dengan metode mixed methods adalah pendekatan penelitian dengan pendekatan penyelidikan secara kuantitatif dan kualitatif, yaitu penggabungan antara dua data, dan menggunakan desain berbeda yang dapat melibatkan asumsi filosofi dan kerangka teoritis. Peneliti harus memiliki keyakinan dalam suatu paradigma sebagai orientasi filosofis dari penelitian dan studi yang dilakukan terus meningkat sejalan dengan orientasi disiplin serta pengalaman peneliti pada desain bangunan sebelumnya.

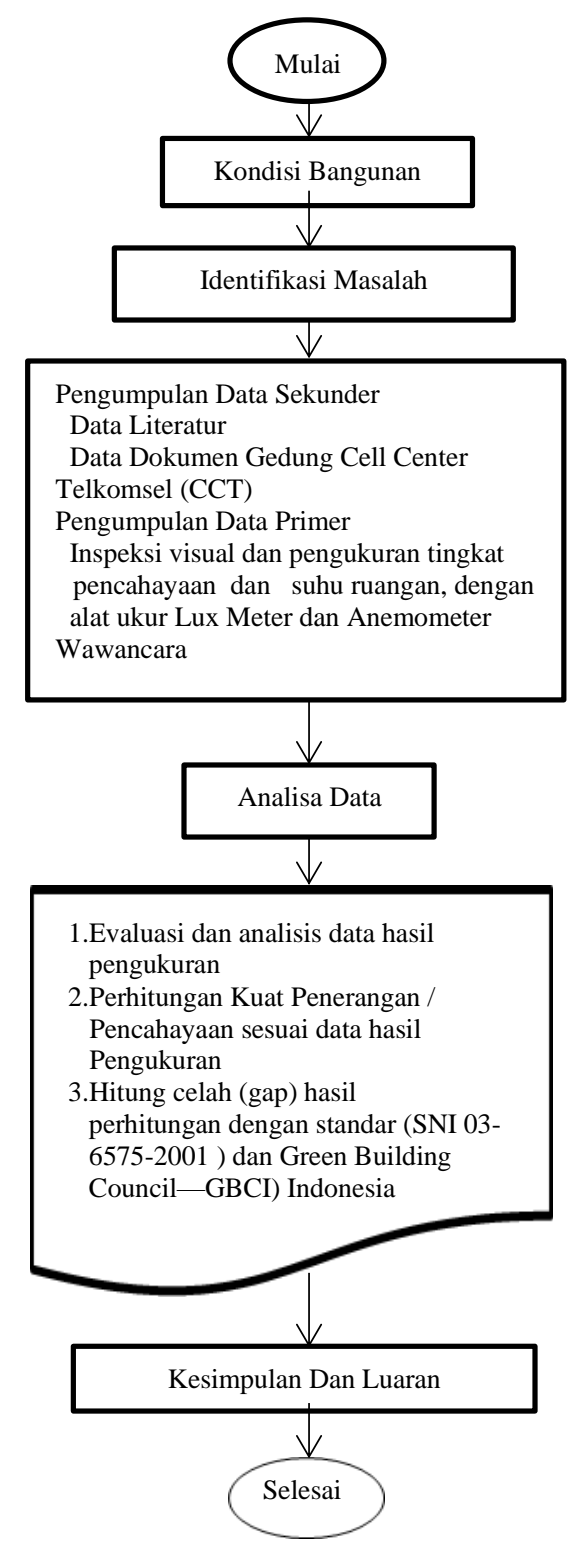

Gambar 4. Diagram Alir Metodologi Penelitian

\subsection{Metode Pengumpulan Data}

Data hasil survei dan pengukuran lebih lanjut dianalisis dan diuji dengan acuan standar dan persyaratan yang ditetapkan. Hasil uji dan perbandingan standar menjadi pendekatan bagi peneliti untuk perhitungan ulang serta desain ulang fisik sebagai salah satu luaran penelitian. Pada penelitian ini akan dilakukan dua perancangan yaitu terdiri dari perancangan sun shading dan perancangan lampu. Tujuan dari perancangan sun shading yaitu untuk mengoptimalkan pencahayaan alami, sedangkan 
perancangan lampu bertujuan agar penggunaan lampu di Gedung CCT lebih efisien. Perancangan ulang juga didasarkan pada SNI 03-6575-2001 dan SNI 03-6197-2000 tentang pencahayaan yang baik untuk gedung perkantoran. serta Peraturan Menteri PUPR No. 02 Tahun 2015 tentang Bangunan Gedung Hijau seperti yang diatur pada[11]. Dalam penelitian ini desain yang dilakukan merupakan desain fasad Gedung CCT dengan penempatan sun shading yang berfungsi untuk pengoptimalisasian pencahayaan alami.

\section{ANALISIS DATA DAN PEMBAHASAN}

\subsection{Pengukuran Pencahayaan Luar Gedung}

Hasil pengukuran yang dilakukan pada periode waktu pagi (8.50 - 9.15 WIB), siang (11.30-11.45 WIB) serta sore (15.00-15.15 WIB) didapat hasil rata-rata berturut-turut sebesar 13094 lux, 20035 lux dan 6759 lux.

\subsection{Pengukuran Pencahayaan Luar Gedung}

Berdasarkan persetujuan dari pihak yang berkepentingan pada gedung CCT, pengukuran pencahayaan hanya akan dilakukan pada bagian dalam gedung mulai dari lantai 1 sampai dengan lantai 4 yang memungkinkan untuk dilakukan pengukuran. Pada setiap ruangan jumlah dari titik pengukuran berbeda-beda.

\section{Pengukuran Pencahayaan Lantai 1}

Dari hasil pengukuran intensitas pencahayaan alami pada Ruang Kerja (Office) Lantai 1 didapat hasil seperti tabel berikut:

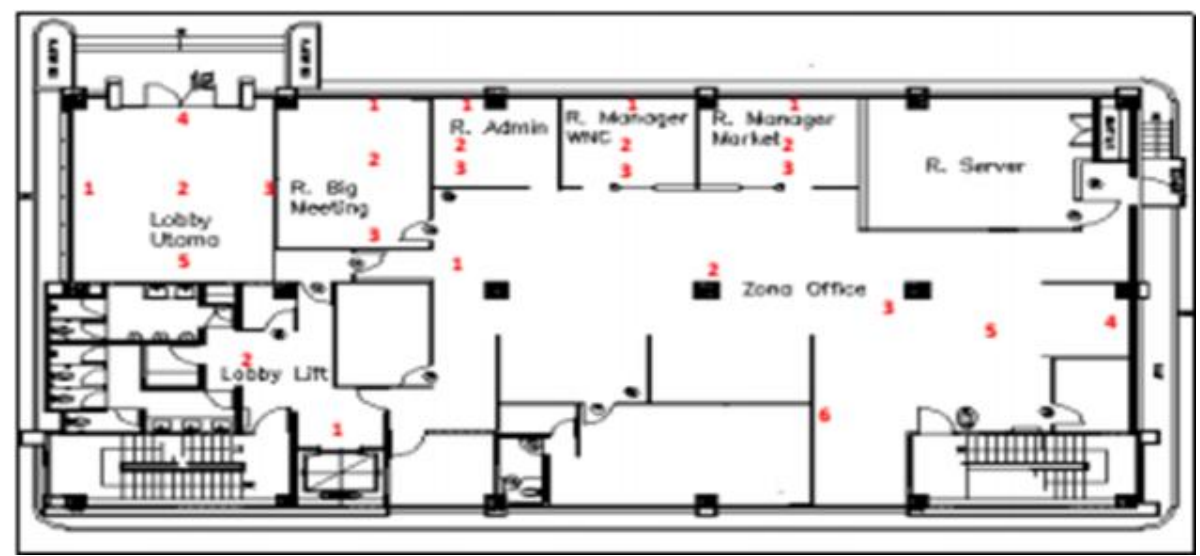

Gambar 5. Denah Gedung CCT Lantai 1

Tabel 1. Hasil Pengukuran Pencahayaan Lantai 1

\begin{tabular}{|c|c|c|c|c|}
\hline \multirow{3}{*}{$\begin{array}{c}\text { Nama } \\
\text { Rg }\end{array}$} & \multirow{3}{*}{ Waktu } & \multicolumn{2}{|c|}{ TU 3 Lampu } & \multirow{3}{*}{$\begin{array}{c}\text { Standar SNI } \\
\text { (Lux) }\end{array}$} \\
\hline & & Off & On & \\
\hline & & Lux & Lux & \\
\hline \multirow{2}{*}{$\begin{array}{l}\text { Zona } \\
\text { Office }\end{array}$} & $9.00-9.30$ & 107 & 155 & \multirow[t]{2}{*}{350} \\
\hline & $15.00-15.30$ & 27 & 117 & \\
\hline
\end{tabular}

Tabel 2. Analisis Hasil Pencahayaan Terhadap SNI

\begin{tabular}{|c|c|c|c|c|}
\hline \multirow{3}{*}{$\begin{array}{c}\text { Nama } \\
\text { Rg }\end{array}$} & \multirow{3}{*}{ Waktu } & \multicolumn{2}{|c|}{ TU 3 Lampu } & \multirow{3}{*}{$\begin{array}{c}\text { Standar SNI } \\
\text { (Lux) }\end{array}$} \\
\hline & & Off & On & \\
\hline & & Lux & Lux & \\
\hline \multirow{2}{*}{$\begin{array}{l}\text { Zona } \\
\text { Office }\end{array}$} & $9.00-9.30$ & 30,6 & 44,3 & \multirow[t]{2}{*}{350} \\
\hline & $15.00-15.30$ & 7,71 & 33,4 & \\
\hline
\end{tabular}

Hasil pengukuran didapat bahwa pencahayaan alami di zona office pada titik ukur 3 (TU3) tidak memenuhi persyaratan SNI, dikarenakan cahaya matahari tidak dapat menjangkau bidang kerja pada titik ukur tersebut.

\section{Pengukuran Pencahayaan Lantai 2}

Pengukuran intensitas pencahayaan alami pada Ruang Kerja (Office) Lantai 2 didapat hasil seperti tabel berikut: 


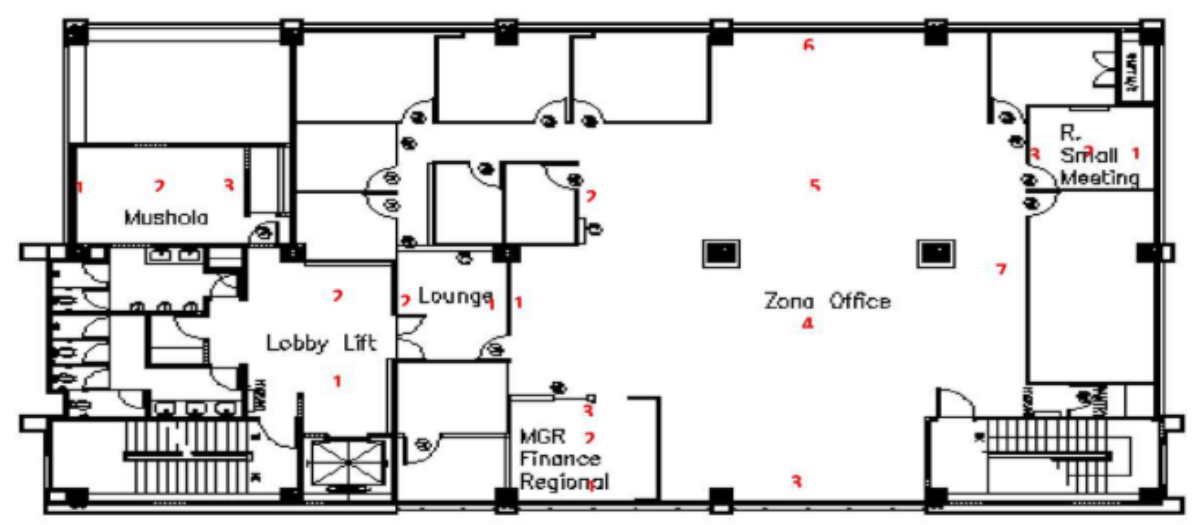

Gambar 6. Denah Gedung CCT Lantai 2

Tabel 3. Hasil Pengukuran Pencahayaan Lantai 2

\begin{tabular}{|c|c|c|c|c|}
\hline \multirow{2}{*}{$\begin{array}{c}\text { Nama } \\
\text { Rg }\end{array}$} & \multirow{2}{*}{ Waktu } & TU 3 Lampu & \multirow{2}{*}{$\begin{array}{c}\text { Standar SNI } \\
\text { (Lux) }\end{array}$} \\
\cline { 3 - 4 } & & Lux & Lux & \\
\cline { 3 - 4 } $\begin{array}{l}\text { Zona } \\
\text { Office }\end{array}$ & $10.30-11.30$ & 4080 & 4190 & 350 \\
\cline { 2 - 4 } & $16.15-16.45$ & 658 & 776 & \\
\hline
\end{tabular}

Tabel 4. Analisis Hasil Pencahayaan Terhadap SNI

\begin{tabular}{|c|c|c|c|c|}
\hline \multirow{3}{*}{$\begin{array}{c}\text { Nama } \\
\text { Rg }\end{array}$} & \multirow{3}{*}{ Waktu } & \multicolumn{2}{|c|}{ TU 3 Lampu } & \multirow{3}{*}{$\begin{array}{c}\text { Standar SNI } \\
(\text { Lux })\end{array}$} \\
\hline & & Off & On & \\
\hline & & Lux & Lux & \\
\hline \multirow{2}{*}{$\begin{array}{l}\text { Zona } \\
\text { Office }\end{array}$} & $10.30-11.30$ & 4080 & 4190 & \multirow[t]{2}{*}{350} \\
\hline & $16.15-16.45$ & 658 & 776 & \\
\hline
\end{tabular}

Hasil pengukuran didapat bahwa pencahayaan alami di zona office pada titik ukur 3 (TU3) sangat berlebihan sehingga efek silau dan radiasi panas pada bidang kerja pada titik ukur tersebut melebihi standar SNI.

\section{Pengukuran Pencahayaan Lantai 3}

Pengukuran intensitas pencahayaan alami pada Ruang Kerja (Office) Lantai 3 didapat hasil seperti tabel berikut,

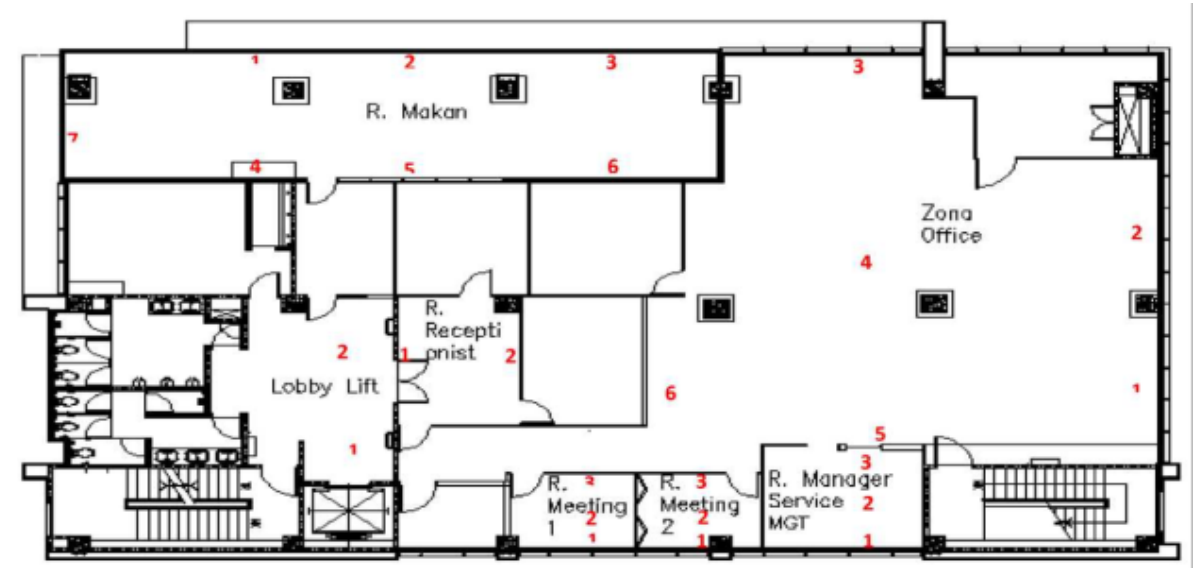

Gambar 7. Denah Gedung CCT Lantai 3

Tabel 5. Hasil Pengukuran Pencahayaan Lantai 3

\begin{tabular}{|c|c|c|c|c|}
\hline \multirow{3}{*}{$\begin{array}{c}\text { Nama } \\
\mathrm{Rg}\end{array}$} & \multirow{3}{*}{ Waktu } & \multicolumn{2}{|c|}{ TU 3 Lampu } & \multirow{3}{*}{$\begin{array}{c}\text { Standar SNI } \\
\text { (Lux) }\end{array}$} \\
\hline & & Off & On & \\
\hline & & Lux & Lux & \\
\hline \multirow{2}{*}{$\begin{array}{l}\text { Zona } \\
\text { Office }\end{array}$} & $10.30-11.30$ & 4750 & 3850 & \multirow[t]{2}{*}{350} \\
\hline & $16.15-16.45$ & 1190 & 1280 & \\
\hline
\end{tabular}


Tabel 6. Analisis Hasil Pencahayaan Terhadap SNI

\begin{tabular}{|c|c|c|c|c|}
\hline \multirow{3}{*}{$\begin{array}{c}\text { Nama } \\
\text { Rg }\end{array}$} & \multirow{3}{*}{ Waktu } & \multicolumn{2}{|c|}{ TU 3 Lampu } & \multirow{3}{*}{$\begin{array}{c}\text { Standar SNI } \\
(\text { Lux })\end{array}$} \\
\hline & & Off & On & \\
\hline & & Lux & Lux & \\
\hline \multirow{2}{*}{$\begin{array}{l}\text { Zona } \\
\text { Office }\end{array}$} & $10.30-11.30$ & 1357 & 1100 & \multirow[t]{2}{*}{350} \\
\hline & $16.15-16.45$ & 340 & 366 & \\
\hline
\end{tabular}

Sama seperti hasil pengukuran pada lantai 2, maka hasil pengukuran pencahayaan alami di zona office pada titik ukur 3 (TU3) sangat berlebihan sehingga efek silau dan radiasi panas pada bidang kerja pada titik ukur tersebut melebihi standar SNI.

\section{Pengukuran Pencahayaan Lantai 4}

Pengukuran intensitas pencahayaan alami pada Ruang Kerja (Office) Lantai 4 didapat hasil seperti tabel berikut,

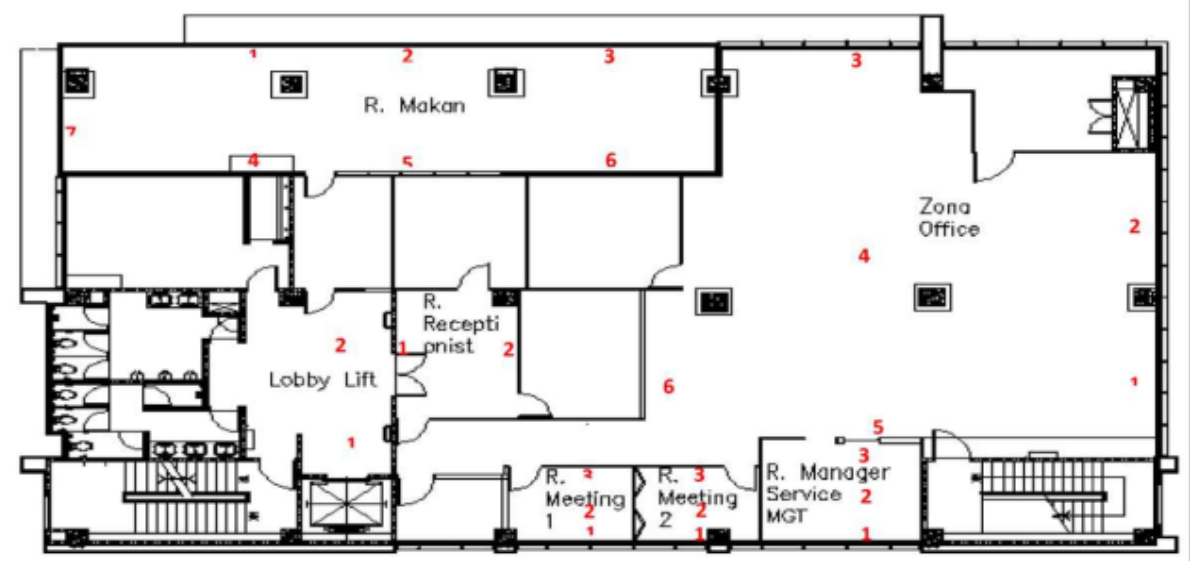

Gambar 8 Denah Gedung CCT Lantai 4

Tabel 7. Hasil Pengukuran Pencahayaan Lantai 4

\begin{tabular}{|c|c|c|c|c|}
\hline \multirow{3}{*}{$\begin{array}{c}\text { Nama } \\
\text { Rg }\end{array}$} & \multirow{3}{*}{ Waktu } & \multicolumn{2}{|c|}{ TU 3 Lampu } & \multirow{3}{*}{$\begin{array}{c}\text { Standar SNI } \\
(\text { Lux })\end{array}$} \\
\hline & & Off & On & \\
\hline & & Lux & Lux & \\
\hline \multirow{2}{*}{$\begin{array}{l}\text { Zona } \\
\text { Office }\end{array}$} & $10.30-11.30$ & 178 & 240 & \multirow[t]{2}{*}{350} \\
\hline & $16.15-16.45$ & 44 & 175 & \\
\hline
\end{tabular}

Tabel 8. Analisis Hasil Pencahayaan Terhadap SNI

\begin{tabular}{|c|c|c|c|c|}
\hline \multirow{3}{*}{$\begin{array}{c}\text { Nama } \\
\text { Rg }\end{array}$} & \multirow{3}{*}{ Waktu } & \multicolumn{2}{|c|}{ TU 3 Lampu } & \multirow{3}{*}{$\begin{array}{c}\text { Standar SNI } \\
(\text { Lux })\end{array}$} \\
\hline & & Off & On & \\
\hline & & Lux & Lux & \\
\hline \multirow{2}{*}{$\begin{array}{l}\text { Zona } \\
\text { Office }\end{array}$} & $10.30-11.30$ & 50,9 & 68,6 & \multirow[t]{2}{*}{350} \\
\hline & $16.15-16.45$ & 12,6 & 50,0 & \\
\hline
\end{tabular}

Pengukuran pencahayaan pada lantai 4 ,sama seperti pengukuran pencahayaan pada lantai 1, terlihat bahwa kuat penerangan / pencahayaan pada bidang kerja dengan titik ukur 3 (TU3) tidak memenuhi persyaratan disebabkan oleh jangkauan cahaya matahari yang masuk ke dalam ruangan tersebut tidak optimal.

\subsection{Desain Sun Shading Pada Gedung CCT}

Terdapatnya masalah pencahayaan ataupun panas radiasi yang diakibatkan oleh sinar matahari menyebabkan penghuni tidak nyaman ketika berada di dalam ruangan. Berdasarkan rotasi matahari terhadap bumi, matahari terbit dari arah timur dan tenggelam ke arah barat. Maka dari itu, bangunan yang menghadap ke arah timur atau ke arah barat akan menerima sinar matahari langsung dari matahari sehingga mengakibatkan rasa panas dan silau yang dapat mengganggu kenyamanan penghuni. Hal ini sama dengan kondisi Gedung CCT, di mana bangunan tersebut tampak depan dan belakangnya secara berurutan menghadap ke arah Barat dan Timur. Selain hal tersebut, tampak bagian depan dan belakang fasadnya didominasi oleh kaca sehingga Gedung 
CCT berpotensi besar untuk menerima panas radiasi matahari dan silau yang diakibatkan oleh pancaran sinar matahari tersebut. Dari fenomena tersebut, maka solusi yang dapat dilakukan adalah melakukan perancangan sun shading. Tujuan dari perancangan sun shading yaitu agar sinar matahari langsung dari arah Barat maupun Timur dapat dihindari untuk masuk ke gedung CCT.

Sinar matahari langsung yang dihindari untuk masuk ke ruangan yaitu sinar matahari yang dapat mengakibatkan efek buruk bagi kesehatan. Oleh karena itu, perancangan sun shading ini mengacu pada hal tersebut yang berlangsung antara pukul $09.00-15.00$ WIB.

Desain dimensi sun shading disesuaikan dengan tinggi ruangan pada Gedung CCT tersebut dengan tinggi rata-rata mulai dari muka lantai hingga plafon adalah 2,9 m. Untuk menghalangi sinar matahari langsung dengan ketinggian tersebut, maka dari itu panjang sun shading yang dipilih adalah $1 \mathrm{~m}$ dari dinding kaca dan 1,166 panjang sun shading hingga muka struktur kolom dengan ketebalan 0,07 m. Sedangkan panjang sun shading ke arah selatan/utara maksimumnya mencapai 6,05 m. Pada Gedung CCT Sun shading yang dirancang menempel pada finishing kolom dengan tebal yaitu 0,3 m. Pada setiap lantai dibuat dua bagian sun shading yaitu yang pertama sejajar dengan ketinggian plafon 2,9 m dan yang kedua merupakan pertengahan antara plafon dan permukaan lantai pada ketinggian 1,45 m. Pembuatan dua bagian tersebut didesain sehingga panjang sun shading dari dinding kaca tidak terlalu jauh dan menambah penerangan ruangan dengan memanfaatkan sinar matahari langsung yang memantul dari permukaan sun shading yang berada pada ketinggian 1,45 m. Desain sun shading pada Gedung CCT dibuat secara zig-zag dengan selisih beda tinggi 0,17 meter antar tiap bagian permukaan sun shading. Pada bagian sun shading terdapat dua warna yang berbeda, yaitu warna putih pada bagian horizontal dan warna merah pada bagian vertikal. Warna putih berfungsi untuk memaksimalkan pantulan dari sinar matahari, sedangkan warna merah sebagai ciri khas bangunan Telkomsel. Dimensi tersebut seperti pada Gambar 9.

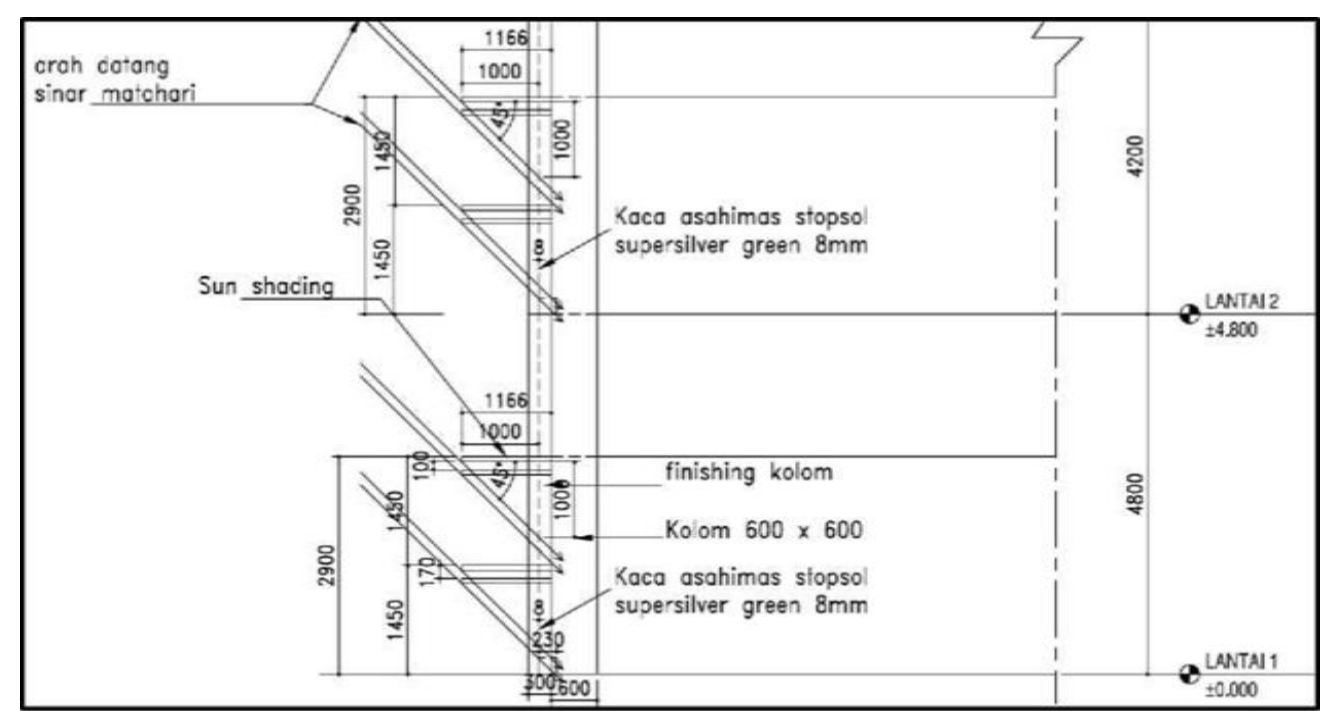

Gambar 9. Desain Sun Shading Gedung CCT

\subsection{Hasil Perhitungan Pencahayaan Alami}

Hasil desain pelindung matahari (sun shading) pada Gedung CCT perlu dibuktikan dengan perhitungan pencahayaan alami yang masuk ke dalam ruangan. Sehingga diketahui seberapa besar manfaatnya terhadap pencahayaan alami yang dihasilkan pada setiap ruang yang ditinjau. Untuk perhitungan ini menggunakan persamaan daylight factor. Selain persamaan tersebut, faktor lain yang digunakan yaitu faktor koreksi transmisi cahaya yang masuk ke dalam ruangan dan persentase refleksi permukaan arsitektur Correction factor stopsol sebesar 0,59. Nilai correction factor ini digunakan sebagai data dalam perhitungan pencahayaan alami. Data yang akan digunakan untuk perhitungan beban Air Conditioner (AC) dengan spesifikasi solar gain faktor dan nilai $\mathrm{U}$ di atas dapat dilihat pada Tabel 9. 
Tabel 9. Spesifikasi Kaca Gedung CCT

\begin{tabular}{|c|c|c|c|c|}
\hline \multirow{2}{*}{ Type of Glass } & Thicknes & Light & Solar Gain & $\mathrm{U}$ \\
\cline { 2 - 5 } & $(\mathrm{mm})$ & transmittance & Factor & $\left(\mathrm{W} / \mathrm{m}^{\circ} \mathrm{C}\right)$ \\
\hline $\begin{array}{c}\text { Stopsol } \\
\text { Supersilver Clear }\end{array}$ & 8 & $67 \%$ & 0,69 & 5,7 \\
\hline $\begin{array}{c}\text { Stopsol } \\
\text { Supersilver Green }\end{array}$ & 8 & $49 \%$ & 0,45 & 5,7 \\
\hline
\end{tabular}

Klasifikasi material yang dipilih dengan warna permukaan yang digunakan untuk bagian dalam terdiri atas dinding, lantai, plafon. Dari ketiga komponen tersebutlah yang akan mempengaruhi pantulan cahaya pada ruangan atau disebut Internal Reflection Component (IRC).

Tabel 10. Pencahayaan Alami Setelah Desain Sun shading

\begin{tabular}{|c|l|c|c|c|c|}
\hline \multirow{3}{*}{ Posisi Ukur } & \multirow{2}{*}{ Nama Ruang } & \multicolumn{4}{|c|}{ Pencahayaan Alami (Lux) } \\
\cline { 3 - 6 } & & \multicolumn{2}{|c|}{ Sebelum Desain } & \multicolumn{2}{c|}{ Setelah Desain } \\
\cline { 2 - 5 } & Terdekat & Terjauh & Terdekat & Terjauh \\
\hline \multirow{4}{*}{ Lantai 1 } & R. Big Meeting & 485 & 8 & 304 & 20 \\
\cline { 2 - 6 } & R. Admin & 663 & 19 & 368 & 49 \\
\cline { 2 - 6 } & R. Mgr WNC & 746 & 21 & 449 & 59 \\
\cline { 2 - 6 } & R. Mgr Marketing & 945 & 50 & 528 & 70 \\
\hline \multirow{5}{*}{ Lantai 2 } & R. Mgr Finance & 864 & 85 & 391 & 64 \\
\cline { 2 - 6 } & Zona Office (West) & 181 & 28 & 112 & 38 \\
\cline { 2 - 6 } & Zona Office (East) & 658 & 28 & 453 & 38 \\
\hline \multirow{5}{*}{ Lantai 3 } & R. Small Meeting 1 & 1698 & 388 & 802 & 173 \\
\cline { 2 - 6 } & R. Small Meeting 2 & 1635 & 266 & 704 & 152 \\
\cline { 2 - 6 } & R. Mgr Service & 1092 & 233 & 862 & 144 \\
\cline { 2 - 6 } & Zona Office & 1190 & 150 & 589 & 144 \\
\hline & R. Meeting & 1803 & 130 & 773 & 150 \\
\cline { 2 - 6 } & R. Chanel & 1077 & 109 & 875 & 170 \\
\cline { 2 - 6 } & Zona Office (West) & 23202 & 44 & 858 & 109 \\
\cline { 2 - 6 } & Zona Office (East) & 2820 & 44 & 798 & 109 \\
\hline
\end{tabular}

Dari hasil analisis dan perhitungan dapat dilihat bahwa sun shading sangat berpengaruh terhadap efisiensi pemakaian energi.

\section{KESIMPULAN DAN SARAN}

1. Desain selimut bangunan dengan material kaca terbukti mengonsumsi energi listrik yang tinggi sehingga kondisi seperti ini memberikan kontribusi besar bagi pemanasan global.

2. Berdasarkan hasil pengukuran dengan lux meter jumlah pencahayaan alami ketika Gedung CCT menggunakan sun shading pada umumnya iluminasi cahaya alami pada jarak terdekat terhadap bukaan mengalami penurunan akibat berkurangnya cahaya langsung yang masuk ke dalam bangunan yang terhalangi shading. Adapun peningkatan iluminasi pada titik terjauh disebabkan akibat sun shading berfungsi sebagai external reflector yang memantulkan cahaya matahari ke arah plafon. Pada bagian tertentu yang mana titik terjauh di mana penerangan alaminya tidak meningkat adalah akibat sudut refleksi yang tidak memungkinkan mengenai bidang pantul yang menerangi bagian ruang terjauh tersebut.

\section{DAFTAR PUSTAKA}

[1]. Suryabrata, Jatmika, (2012); "Principles and Applications Green Design.”, Universitas Gajah Mada, Yogyakarta.

[2]. Kivimaa, Paula \& Mari Martiskainen, (2017). Innovation, Low Energy Buildings and Intermediaries in Europe: Systematic Case Study Review, Reviewarticle, Energy Efficiency , 11 (1), 31-51. .DOI 10.1007/S12053-017-9547-Y 10 July 2017.

[3]. Liu C, Wang X. (2000), Curtain wall technology of green building. Journal of Chongqi University of Architecture, 22(5):27-31.

[4]. Lechner, N. (2008). Heating, Cooling, Lighting: Sustainable Design Methods for Architects. Hoboken, N.J.: Wiley. 
[5]. Prowler, Don. (September 2016). "Sun Control and Shading Device”. Diakses tanggal 6 February dari https://www.wbdg.org/resources/sun-control-and-shadingdevices

[6]. Satwiko, Prasasto. (2008). "Fisika Bangunan". Yogyakarta: Andi.

[7]. McGuinness, William J., Benjamin Stein dan John Reynolds. (1986). "Mechanical and Electrical Equipment for Building, 6th ed. U.S.A.: Wiley.

[8]. Creswell, J.W. (2015). A concise introduction to mixed methods research. Sage Publications

[9]. Creswell, J. W. (2013). What is mixed methods research [video file]. Retrieved from ttps://www.youtube.com/watch.

[10]. Green Building Council Indonesia. (Juni 2016). “Greenship Existing Building Version 1.1”. Diakses tanggal 12 November 2016 dari http://gbcindonesia.org/.

[11]. Peraturan Menteri Pekerjaan Umum Dan Perumahan Rakyat RI No 02 (2015); “ Bangunan Gedung Hijau” 